\title{
Efficiency of quality of triggering system and pressurization of home care ventilators. a bench
}

\author{
L Baboi ${ }^{*}$, S Guegan², C Guérin ${ }^{3,4}$ \\ From ESICM LIVES 2015 \\ Berlin, Germany. 3-7 October 2015
}

\section{Introduction}

Turbine home care ventilators can be used in the hospital to manage patients with hypercapnic acute respiratory failure. The goal of this study was to assess efficiency of quality of triggering system and pressurization of these ventilators.

\section{Methods}

Astral 150, Elisée 150, Trilogy 200, Monnal T50 (double limb circuit) and Evita XL were set in pressure support (PS) $15 \mathrm{~cm} \mathrm{H} 2 \mathrm{O}$ with positive end expiratory pressure (PEEP) $5 \mathrm{cmH} 2 \mathrm{O}$. In each ventilator the specific leak compensation system was activated. Each ventilator was used with its optimal inspiratory triggering system facing leaks. Inspiratory trigger was set at maximum sensitivity avoiding autotriggering. The ventilators were connected to ASL 5000 lung model set in a condition mimicking COPD patient (compliance $75 \mathrm{ml} / \mathrm{cmH} 2 \mathrm{O}$, inspiratory and expiratory airways resistance 15 and $25 \mathrm{cmH} 2 \mathrm{O} / \mathrm{L} /$ $\mathrm{s}$, respectively). We compared low, moderate and strong inspiratory efforts $(-3,-6$ and $-12 \mathrm{~cm} \mathrm{H} 2 \mathrm{O}$ muscular pressure, respectively) with and without calibrated non intentional leak (NIL $20 \mathrm{~L} / \mathrm{min}$ at $15 \mathrm{~cm} \mathrm{H} 2 \mathrm{O}$ ). Pressure time product (PTP) of the triggering system (PTPtrig) was measured over 10 breaths as the area subtended by the pressure over the time spent between onset of inspiratory effort and start of pressurization (time unsupported). PTP500 was measured between onset of inspiratory effort and $500 \mathrm{~ms}$ after. When time unsupported was greater than $500 \mathrm{~ms}$ (delayed effort) PTP500 was set to 0 . Measured PTP500 was compared to ideal PTP500, which is equal to PS level achieved at the end of inspiration x $500 \mathrm{~ms}$ (PTP\%ideal).

Values were expressed as mean $\pm \mathrm{SD}$. Comparisons were made by using one-factor ANOVA and multiple

${ }^{1}$ Hôpital de la Croix Rousse, Lyon, France

Full list of author information is available at the end of the article comparisons between ventilators by using Tukey test. Significant statistical threshold was set to $\mathrm{P}<0.001$ to take into account the number of statistical tests performed.

\section{Results}

For PTPtrig with NIL, there were marked differences across ventilators for low and moderate efforts that were no longer present for strong effort (Figure). Without NIL, the results were in the same direction. Significant differences were observed between ventilators for PTP500 at each effort with or without NIL. The same was true for PTP500\%ideal. As an example, for strong effort without NIL, PTP500\%ideal averaged $70 \pm 1 \%$ for Astral, $70 \pm 2 \%$ for Elisée, $55 \pm 1 \%$ for Evita XL, $50 \pm$ $1 \%$ for Monnal T50 and $34 \pm 4 \%$ for Trilogy $(\mathrm{P}<0.001$ between ventilators). With NIL, these values were $73 \pm$ $12,32 \pm 40,66 \pm 29,58 \pm 26$ and $35 \pm 21(\mathrm{P}<0.001$ between ventilators), respectively.

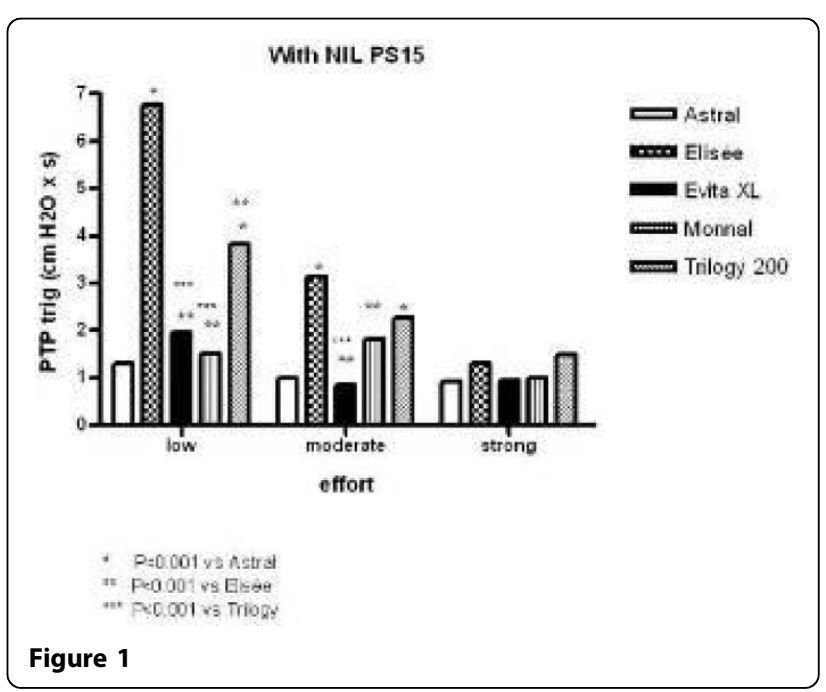




\section{Conclusions}

There were marked differences in PTPtrig between ventilators that were also dependent on intensity of effort. The overall quality of PS mode as assessed in present study, was significantly different across the ventilators tested, with the Astral ventilator exhibiting best performance.

\section{Authors' details}

${ }^{1}$ Hôpital de la Croix Rousse, Lyon, France. ${ }^{2}$ Ecole des Haute Etudes Ingenieur, Lille, France. ${ }^{3}$ Hopital de la Croix Rousse, Lyon, France. ${ }^{4}$ INSERM UMR 955,

Créteil, France.

Published: 1 October 2015

doi:10.1186/2197-425X-3-S1-A272

Cite this article as: Baboi et al:: Efficiency of quality of triggering system

and pressurization of home care ventilators. a bench. Intensive Care

Medicine Experimental 2015 3(Suppl 1):A272.

\section{Submit your manuscript to a SpringerOpen ${ }^{\mathcal{O}}$ journal and benefit from:}

- Convenient online submission

- Rigorous peer review

- Immediate publication on acceptance

- Open access: articles freely available online

- High visibility within the field

- Retaining the copyright to your article

Submit your next manuscript at $>$ springeropen.com 